\title{
ASSESSING ENGLISH PRE-SERVICE TEACHERS' KNOWLEDGE BASE OF TEACHING: LINKING KNOWLEDGE AND SELF-PORTRAYAL
}

\author{
Anita Triastuti \\ (anitatria@uny.ac.id) \\ Universitas Negeri Yogyakarta \\ Jl. Colombo No.1, Karang Malang, Caturtunggal, \\ Sleman, Yogyakarta 55281
}

\begin{abstract}
This study aimed to assess pre-service teachers' knowledge base of teaching and the extent they perceive and reflect its implementation in a microteaching course. Employing mixed-methods design, the study involved pre-service teachers in a state university in Special Territory of Yogyakarta. The quantitative data were collected from a test on the pre-service teachers' understanding of teacher knowledge base of teaching and a survey of their perceptions towards the implementation of teacher knowledge base of teaching in their microteaching practices. The qualitative data were gathered from the preservice teachers' reflections. The findings showed that despite the overall good test score average of the pre-service teachers' knowledge base of teaching and the generally positive self-rating perceptions, the pre-service teachers' limited and descriptive reflections did not sufficiently depict their actual implementation of teacher knowledge base of teaching in their microteaching practices.
\end{abstract}

Keywords: English pre-service teachers, teacher knowledge base of teaching, perceptions, reflections

DOI: http://dx.doi.org/10.15639/teflinjournal.v31i1/108-138

Teacher knowledge base of teaching has been claimed fundamental to nurture teacher pedagogical reasoning for the development of effective instruction (Gudmundsdottir \& Shulman, 1987). In the context of English as a foreign language (EFL) or that of English as a second language (ESL), teacher knowledge base of teaching has been researched to explore how teacher knowledge categories within teacher knowledge base of teaching closely 
interact and influence each other when teachers design and enact their instruction (e.g., Johnston \& Goettsch, 2000; König et al., 2016; Myhill, Jones, \& Watson, 2013; Sanchez \& Borg, 2014). These studies show how teachers' instructional practices, particularly the experienced teachers', exhibit a complex and multifaceted interaction of knowledge categories derived from teacher knowledge base of teaching. Such interaction, therefore, signifies teacher expertise.

Expert experienced teachers are marked by their ability in integrating teacher knowledge base of teaching to develop complex and coherent instruction (Tsui, 2003). Despite the accountability of experience that may contribute to the expertise of experienced teachers, teachers' prior language learning, through the apprenticeship of observation (Lortie, 1975), plays a crucial role in developing their cognition, and, consequently, informs their classroom practices (Bailey et al., 1996; Holt-Reynolds, 1992). This argument justifies that pre-service teachers' observations as language learners in their teacher education shape their ability in managing effective instruction (Johnson, 1994) and further form "the construction of their professional identities" (Trent, 2013, p. 436). It is, therefore, possible to maximize preservice teachers' expertise by providing a rewarding apprenticeship of observation. Such apprenticeship enables them to gain rewarding learning process and experience. As Farrell (2013) states, rewarding experience strives for the balance of teaching practices, and self-awareness, which involves reflexive self-observation, self-monitoring, and self-control. Thus, the aforementioned studies on EFL/ESL teacher knowledge confirm that the extent of teachers' ability in integrating teacher knowledge base of teaching reflects the degree of their expertise and that pre-service teachers' apprentice of learning shapes their early expertise development. While experienced teachers' expertise has been widely researched, novice and pre-service teachers' expertise is yet to explore.

This present study is, therefore, aimed at assessing pre-service teachers' initial expertise development by investigating the extent to which they understand teacher knowledge base of teaching, and perceive and reflect its implementation in their microteaching class, which is a part of their teaching practicum. The results and findings of the study are expected to portray their teacher knowledge base of teaching and actual challenges they experience when conducting their microteaching practices. The identification of preservice teachers' teaching challenges is beneficial to inform future endeavors 
by teacher education in providing relevant and rewarding learning processes and experiences for them.

\section{Knowledge Base of Teaching and Pre-Service Teachers' Initial Development of Teaching Competence}

Knowledge base of teaching is drawn from Shulman's $(1986,1987)$ model of pedagogical reasoning. Grounded on this model, teachers' sound pedagogical reasoning for their instructional purposes departs from their engagement with their knowledge base of teaching, comprising: (1) content knowledge (CK), (2) pedagogical content knowledge (PCK), (3) curricular knowledge, (4) general pedagogical knowledge (PK), (5) knowledge of aims and purposes, (6) knowledge of learners, and (7) knowledge of educational contexts, settings, and governance (Gudmundsdottir \& Shulman, 1987; Shulman, 1986, 1987). Anchored to the influential work by Shulman (1986, 1987), a number of studies on second language (L2) teacher knowledge have confirmed English teachers' ability, both experienced and inexperienced ones', in recalling and connecting an array of their knowledge base of teaching (e.g., Atay et al. 2010; Gatbonton, 2008; Johnston \& Goettsch, 2000; König et al., 2016; Mullock, 2006; Myhill et al., 2013; Richards, Li, \& Tang, 1995; Sanchez $\&$ Borg, 2014). In these studies, these two kinds of teachers are described to demonstrate different degrees of teacher expertise. Unlike experienced teachers, who were able to orchestrate their multidimensional teacher knowledge base of teaching (Myhill et al., 2013; Richards et al., 1995; Sanchez \& Borg, 2014), inexperienced teachers, including pre-service teachers, exhibited a less complex interaction of their knowledge base (Atay et al., 2010; Richards et al., 1995). However, pre-service teachers were potentially able to display a range of complex interactions of teacher knowledge base of teaching depending on their learning stages at their teacher education program (König et al., 2016). In the same manner, novice teachers possibly demonstrate similar expertise to those shown by experienced teachers at their early stage of their teaching career (Gatbonton, 2008; Mullock, 2006).

In managing the interaction of knowledge categories within teacher knowledge base of teaching, pre-service and early career teachers experience problems and challenges. Research on novice and pre-service teachers' initial development of their knowledge and teaching competence (e.g., Komur, 2010; König et al., 2016; Kwo, 1996; Numrich, 1996; Yan \& He, 2010) describe 
varied challenges, problems, concerns and frustrations experienced by novice and pre-service teachers in transforming their knowledge base for instructional purposes during their early teaching career and teaching practicum. The studies by Komur (2010) and König et al. (2016) assessed pre-service teachers' knowledge base of teaching which consisted of content knowledge (CK), general pedagogical knowledge (GPK) and pedagogical content knowledge (PCK). These studies revealed that pre-service teachers were able to obtain sufficient scores in the teacher knowledge base test. The study by König et al. (2016) confirmed that the more extended the learning opportunities pre-service teachers had obtained at their teacher education program, the better they performed on the test. The pre-service teachers at the induction phase performed better than those in the early stage of their study. Hence, the advanced learning opportunities these pre-service teachers obtained at the induction phase supported their better understanding of GPK and PCK. The study conducted by Komur (2010), however, discovered that despite sufficient scores the pre-service teachers obtained in the teaching knowledge test, they encountered a range of problems in teaching grammar and language skills, and in managing a classroom. Such problems were particularly caused by the preservice teachers' inability in connecting theories to their experiential learning in order to cope with their students' learning difficulties. Managing a classroom also appeared to be a big challenge in the studies conducted by Kwo (1996), Numrich (1996), and Yan and He (2010). These studies argue that novice and pre-service teachers are strongly concerned with setting up routines, developing rapport, and maintaining classroom flow and order. Their concern is contributed by their lack of practical knowledge to cope with classroom reality (Yan \& He, 2010).

Practicing reflection is largely promoted to help pre-service teachers address their complex experiences in developing their initial expertise and become more proficient teachers (see, e.g., Chien, 2014; Komur, 2010; Makina, 2018). It is agreed that reflections during teaching practicum and classroom teaching experience can navigate pre-service teachers to connect theory and practice so as to help them gain their initial professional development and sustain their professional growth. This is because when stimulated by reflective exercises during teaching practicum, pre-service teachers are critically engaged to "observe, inquire, acquire, construct and reconstruct, and practice pedagogical awareness and knowledge" (Chien, 2014, p. 831). Therefore, it is crucial that teacher education programs provide pre-service teachers with as 
many opportunities as possible to self-reflect during their teaching practicum. Research on reflective practice at teaching practicum have prescribed such particular activities in which reflections are integrated into pre-service teachers' experiential learning (e.g., Chien, 2014; Korkko et al., 2016; Makina, 2018; Parsons \& Stephenson, 2005; Stenberg et al,, 2016). In these studies, preservice teachers' reflective practice was facilitated and measured. The studies by Chien (2014), Parsons and Stephenson (2005), and Stenberg et al. (2016) stimulated pre-service teachers to self-reflect on and make sense of their teaching practicum by applying simulated teaching practice and oral interviews, a close collaboration and partnership with peers and members of school staff, and a thematic practicum over a conventional class teacher practicum. Meanwhile, Makina (2018), and Korkko et al. (2016) made use of daily journal entries and portfolio writings to measure the contents and levels of pre-service teachers' reflections.

Such interventions to promote pre-service teachers' reflective practice need to be incorporated into teacher education programs to develop pre-service teachers' reflection and evaluate the level of their reflection. It is also important to examine the extent to which pre-service teachers' experiential learning has transformed their descriptive reflections into critical ones (Loo et al., 2019). Loo et al. (2019), further, emphasize that by engaging in critical reflections, pre-service teachers would be able to involve evaluations of pedagogical reasoning in their future instructional practices. Thus, incorporating pre-service teachers' reflections in portraying their initial professional development during teaching practicum is a recommended measure to do, as conducted in this present study. In resonance to this crucial measure, this present study focused on discovering: a) pre-service teachers' knowledge base of teaching, and b) the extent to which they perceive and reflect on the implementation of their knowledge base of teaching in their microteaching class.

\section{METHOD}

A total of 30 pre-service teachers (PSTs) from three microteaching classes at English Language Education study program in a university in Special Territory of Yogyakarta participated in this study. The microteaching course is offered to $6^{\text {th }}$ semester student teachers in the program. In the course, the preservice teachers are required to conduct a series of simulated teaching practices in which they treat their peers as middle or high school students. 
Purposive and convenience sampling techniques (Miles, Huberman, \& Saldana, 2014) were adopted to invite these PSTs. Purposive sampling allowed the study to focus on a particular context, which was classroom practices at the aforementioned home study program and university. Meanwhile, convenience sampling provided an immediate and convenient access to the microteaching classes offered at the $6^{\text {th }}$ semester convened by the researcher and her other two colleagues.

This study employed mixed methods with an emphasis on the use of quantitative and qualitative designs for triangulation and complementarity purposes (Riazi, 2017). The quantitative data were obtained from the PSTs' test scores and their perceptions of the implementation of teacher knowledge base of teaching in their microteaching practices. The qualitative data were gathered from their reflections on their learning experience in integrating teacher knowledge base of teaching into their microteaching practices.

Two stages of data collection were sequentially conducted. The first stage of the data collection was to obtain the PSTs' test scores of teacher knowledge base of teaching. The second one was to gather their perceptions and reflections of implementing teacher knowledge base of teaching to effectively develop their microteaching practices. The test for measuring their understanding was conducted in about 120 minutes. In the second stage of data collection, the PSTs completed a self-perception survey in 30 minutes, and then wrote self-reflections in about 60 minutes based on several guiding questions. A 15-minute break was allocated between these data collection activities to provide some time for the PSTs to relax.

The teaching knowledge test consisted of five modules representing five knowledge categories within teacher knowledge base of teaching (Gudmundsdottir \& Shulman, 1987; Shulman, 1986, 1987). The modules comprised: (1) Module 1: knowledge of learners (10 items), (2) Module 2: content knowledge (29 items), (3) Module 3: pedagogical knowledge (49 items), (4) Module 4: knowledge of curriculum (10 items), and (5) Module 5: knowledge of context ( 3 cases). Hence, the modules correspond to the five categories of knowledge within teacher knowledge base of teaching. The proportion of the test items was determined based on the proportion of the essential instructional activities covered within the scope of the aforementioned five knowledge categories of teacher knowledge base of teaching (Gudmundsdottir \& Shulman, 1987; Shulman, 1986, 1987) (see Appendix 1). The test items for knowledge of learners, pedagogical knowledge, and content 
knowledge were taken from Cambridge's Teacher Knowledge Test (Spratt, Pulverness, \& William, 2011), while the items for knowledge of curriculum and knowledge of context were contextually constructed based on the national EFL curriculum.

The PSTs' perceptions were measured by a questionnaire (see Appendix 1), in which they were required to rate the extent to which they implemented the essential instructional activities within teacher knowledge base of teaching in their microteaching practices. Thirty-seven essential instructional activities, which referred to the five knowledge categories tested, were to be rated in three scales: 1) Sufficient, 2) Partially Sufficient, and 3) Not Sufficient. The scope of teacher knowledge categories underlying the construction of the questionnaire items was determined based on Shulman's $(1986,1987)$ classification and definitions of teacher knowledge categories within teacher knowledge base of teaching, and theories of English language learning and teaching.

Finally, the students' reflections were gained from their reflective elaborations on the reflective open-ended questions (see Appendix 2), which consisted of two parts. The first part contained eight reflective open-ended questions to explore the PSTs' experience in implementing teacher knowledge base of teaching. The second one was the same kind of question to capture problems that the PSTs encountered in their microteaching practices.

The construct validity of the questionnaire items, the reflective openended questions, and the test items for knowledge of curriculum and knowledge of context was achieved in three ways: (1) referring to the theories relevant to the five categories of essential knowledge within teacher knowledge base of teaching, (2) obtaining verification from a senior lecturer, a professor with an expertise in Language Curriculum Development, who checked the legibility and the theoretical accuracy of all of the questionnaire items, the questions, and the test items, and (3) conducting a pilot study to measure the readability of the questionnaire items, the questions, and the test items to the target respondents.

The PSTs' test results were gained by calculating the score averages for each knowledge category, while their self-perceptions were analyzed by counting the frequency of the rating scales from each item representing the five knowledge categories of teacher knowledge base of teaching. Manual data analysis (Saldana, 2013) was conducted on the PSTs' reflections on the implementation of teacher knowledge base of teaching in their microteaching practices. The selected data segments were manually analyzed and coded by 
means of process coding in Microsoft Excel as the database repository (Miles et al., 2014; Saldana, 2013). Then, the coded data segments were summarized to infer the PSTs' patterns of pedagogical actions and teaching challenges.

\section{FINDINGS AND DISCUSSION}

\section{Findings}

The results of the study showed that the pre-service teachers' (PSTs') score averages of teaching knowledge test ranged from "fairly good" to "very good". This range of their score averages was consistent with their self-rating perceptions of the extent to which they integrated teacher knowledge base of teaching into their instruction. The PSTs rated "sufficient" for most of the essential instructional activities (see Appendix 1) listed in the four categories of knowledge, except knowledge of context. However, the findings also showed that the PSTs' reflections did not thoroughly visualize their actual implementation of teacher knowledge base of teaching in their microteaching practices. The PSTs were unable to adequately describe their past microteaching practices. Their limited reflections on their microteaching practices indicate their difficulty in reflecting on how the five categories of knowledge in the teacher knowledge base of teaching are put into practice in their microteaching performances. The detailed results and findings of the study are presented below.

\section{Test of Teacher Knowledge Base of Teaching}

The teaching knowledge test (TKT) for measuring the pre-service teachers' (PSTs') understanding of teacher knowledge base of teaching showed that the participants' overall score average upon the five categories of knowledge was 76. Referring to their university's grading system, this overall score average is classified as "good". The PSTs achieved the highest score average in completing the test items for knowledge of curriculum, followed by knowledge of context and pedagogical knowledge, while the score averages for knowledge of learners and content knowledge were fairly similar. The distribution of the score average in each category of knowledge covered in the TKT is shown in Table 1 below. 
116 TEFLIN Journal, Volume 31, Number 1, January 2020

Table 1. Pre-Service Teachers' Score Average in the Test of Teacher Knowledge Base of Teaching

\begin{tabular}{cll}
\hline No. & Knowledge Category & Score Average \\
\hline 1 & Knowledge of Learners & 63 \\
2 & Content Knowledge & 66 \\
3 & Pedagogical Knowledge & 73 \\
4 & Knowledge of Curriculum & 92 \\
5 & Knowledge of Context & 86 \\
\hline Overall score average & 76 \\
\hline
\end{tabular}

As shown in Table 1, the PSTs' score averages for knowledge of learners and content knowledge were 63 (fair) and 66 (fairly good). In completing the test items for knowledge of learners, the PSTs were fairly able to identify learning activities relevant to particular learner characteristics and learner needs. Similarly, they were fairly able to answer the test items on the use of grammar and vocabulary in context. In terms of pedagogical knowledge, the PSTs generally showed "good" understanding as reflected in the score average of 73. Of the pedagogical knowledge-related items, the PSTs did not successfully answer the items focusing on sequencing learning activities, organizing the stages of the lesson, and assessing student learning. Regarding the implementation of knowledge of curriculum and knowledge of context, the PSTs showed very good understanding of essential information about the national EFL curriculum and ways to integrate socio-educational contexts into instruction.

\section{Perceptions of the Implementation of Teacher Knowledge Base of Teaching}

The pre-service teachers' (PSTs') perceptions of the implementation of teacher knowledge base of teaching in their microteaching practices confirmed that overall, the PSTs had integrated the essential instructional activities for the five knowledge categories of teacher knowledge base of teaching (see Appendix 1) sufficiently, although for the category of knowledge of context, most of the PSTs rated the implementation of many of the activities in the category as "partially sufficient".

For the implementation of knowledge of learners (see Figure 1), the PSTs generally felt that they have sufficiently specified and assessed information about the target students to inform their instruction (Activities 1 and 3), with 
$63 \%$ and $56 \%$ of the respondents rated the implementation of these activities as "sufficient". Yet, more than half of them perceived that they were not really able to use feasible ways or techniques in collecting information about the target students (Activity 2), nor were they able to integrate their target students' needs into their instruction (Activity 4). The implementation of these two activities were rated as "partially sufficient" by $56 \%$ of the respondents. In terms of reflective teaching practice, most of the PSTs admitted that they did not fully include their reflection on the impacts of integrating information about the target students in their instruction (Activity 5), as confirmed in $73 \%$ of the respondents' rating this aspect as "partially sufficient". However, $63 \%$ of them perceived that they had sufficiently reflected on the previous instruction to inform their future instruction (Activity 6).

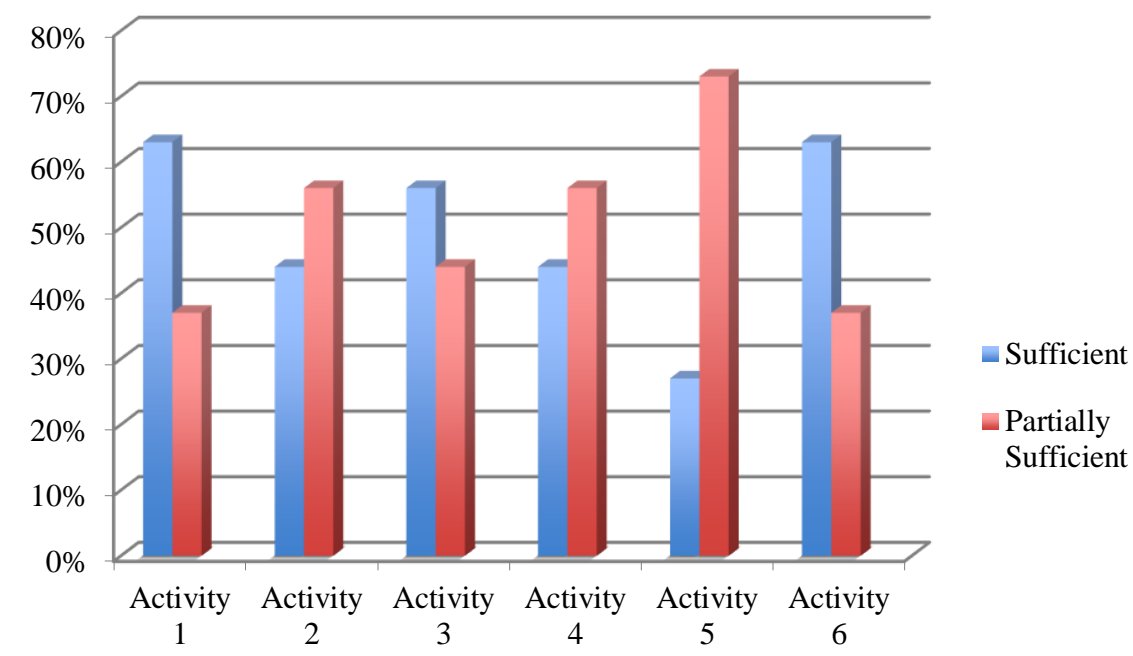

Figure 1. Distribution of Perceptions of Instructional Activities within Knowledge of Learners

In terms of implementing content knowledge, as illustrated in Figure 2, the PSTs confidently felt that they had accommodated sufficient content conceptualization to their microteaching practices; however, they were not really confident about their ability to deliver their content conceptualization for meaningful instruction. Eighty-three percent of the PSTs also perceived that 
they were sufficiently able to identify the required content categories for their instruction (Activities 7-8). They also felt they were fairly able to systematically map content categories (Activity 9), and to transform or change the selected content categories into relevant teaching and learning activities (Activity 10). However, they did not perceive themselves as fully capable of putting their knowledge of content into practice. Sixty-three percent of the respondents rated their implementation of this activity as "partially sufficient".

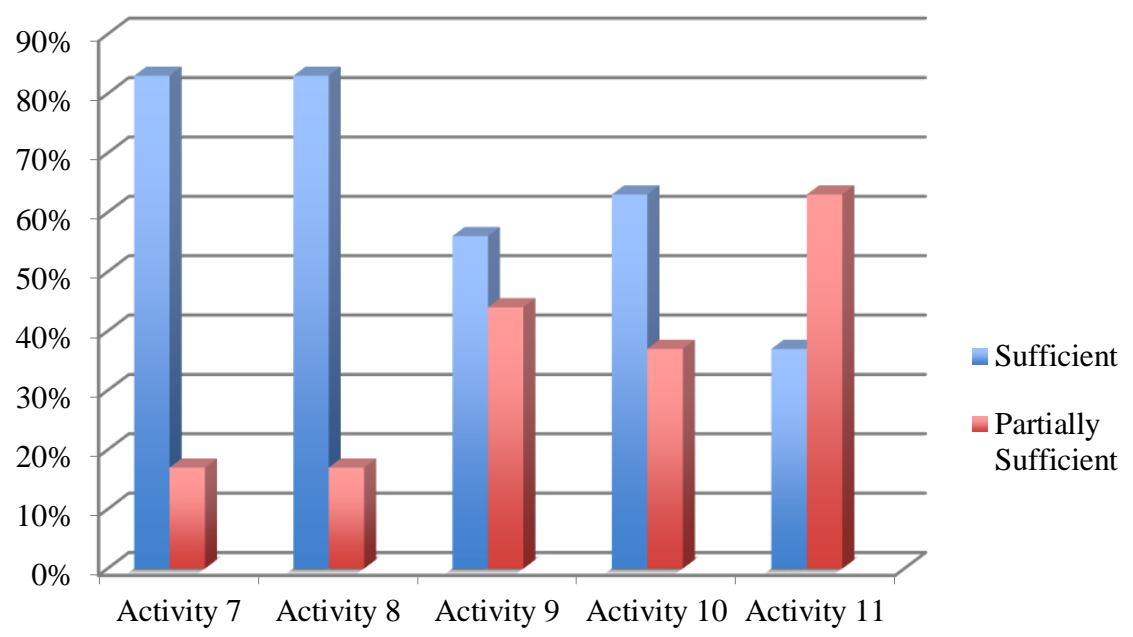

Figure 2. Distribution of Perceptions of Instructional Activities within Content Knowledge

As depicted in Figure 3, among the 18 activities in the category of pedagogical knowledge, the implementation of ten of the activities was rated "sufficient" by the PSTs, while the other eight "partially sufficient". To begin with, most of the PSTs rated the implementation of the essential instructional activities of formulating learning objectives and indicators (Activities 12 and 13 ) as "sufficient", with the percentages of $83 \%$ and $63 \%$ respectively. It is interesting to record that $56 \%$ of the PSTs perceived that they had sufficient understanding of the principles for organizing and sequencing their lessons (Activity 14); however, most of them also felt that their practices for organizing the lesson (Activity 15) and applying relevant activities in accordance with the 
chosen organizing principle (Activity 16) were "partially sufficient", with $80 \%$ and $56 \%$ of the PSTs' responses on the rating scale. On the contrary, despite the PSTs' moderate rate of perceptions that they had sufficient understanding of sequencing their lesson, they confidently perceived that they had sufficiently sequenced their learning activities by using such strategies as simple to difficult, chronological order, pre-requisite learning, complex to less complex, or controlled to freer activities (Activity 17). For the next three essential activities related to developing materials (Activities 18-20), most of the PSTs rated the implementation of selecting and evaluating materials (Activity 18), and that of adapting materials (Activity 19) as "partially sufficient", with the percentages of $63 \%$ and $83 \%$ respectively. However, in terms of considering the authenticity level of materials (Activity 20), 63\% of the PSTs perceived that they had sufficiently done so.

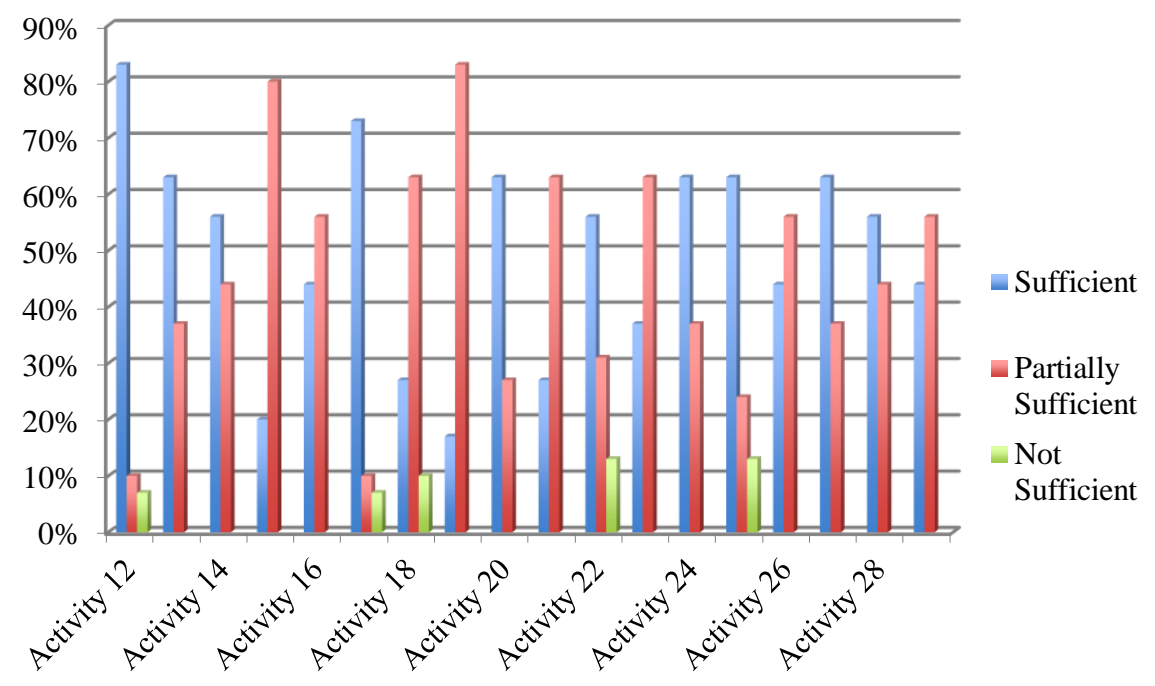

Figure 3. Distribution of Perceptions of Instructional Activities within Pedagogical Knowledge

Concerning the activities of assessing student learning, many of the PSTs rated the implementation of knowledge on designing assessment for learning activities (Activity 21) and developing assessment rubric (Activity 23) as 
"partially sufficient", with $63 \%$ respondents having this perception. However, in terms of applying assessment activities that offer varied performance opportunities (Activity 22), 56\% perceived their implementation as "sufficient". Similarly, in the activities of using media (Activities 24-25) and giving feedback (Activities 27-28), more than 60\% of the PSTs gave "sufficient" rating on their knowledge implementation. Finally, more than half of the respondents rated their implementation of the last two activities related to practicing classroom English (Activity 26) and managing classroom (Activity 29) as "partially sufficient".

In regard to the implementation of knowledge of curriculum, as shown in Figure $4,80 \%$ of the pre-service teachers (PSTs) perceived that they had sufficiently planned and conducted their microteaching practices as required based on the designated core and basic competences in the national EFL curriculum, Curriculum 2013, (Activity 30). However, 60\% of them perceived that they had not sufficiently incorporated such mandated content categories as moral and cultural values, higher order thinking skills, and $21^{\text {st }}$ century learning skills into instruction (Activity 31 ). In terms of reflective teaching practices, $63 \%$ of the PSTs said that they had done some reflection on their past instruction to improve the quality of their future one (Activity 33). Yet, as indicated by $63 \%$ of the respondents, they felt they were not really able to reflect on whether learning had taken place and the learning outcomes had been met (Activity 32).

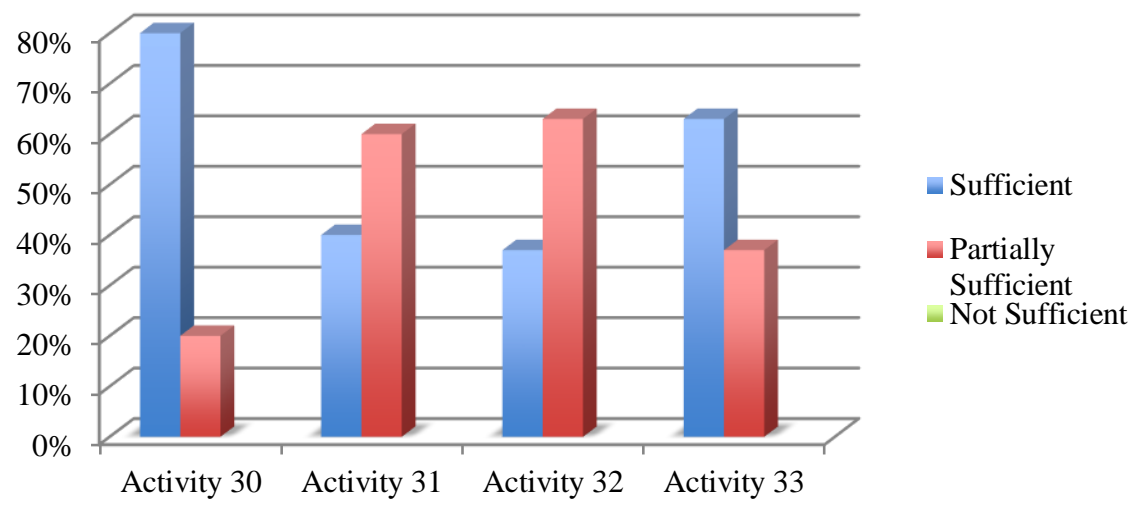

Figure 4. Distribution of Perceptions of Instructional Activities within Knowledge of Curriculum 
Finally, in terms of integrating knowledge of context into instruction (see Figure 5), the pre-service teachers (PSTs), in general, did not fully incorporate this knowledge category into their microteaching practices. Most of the PSTs perceived the implementation of all the four essential activities in the category of knowledge of context (see Appendix 1) as "partially sufficient". More than $60 \%$ of them stated that they did not really consider and include information about context for making pedagogical decisions in planning and implementing instruction (Activities 36-37). More than half of the PSTs also perceived that they did not fully observe the social, cultural, and educational aspects that characterize the context on which instruction is based (Activity 34), nor did they fully gain specific information of the context, for example characteristics, constraints, and strengths, on which instruction is grounded (Activity 35).

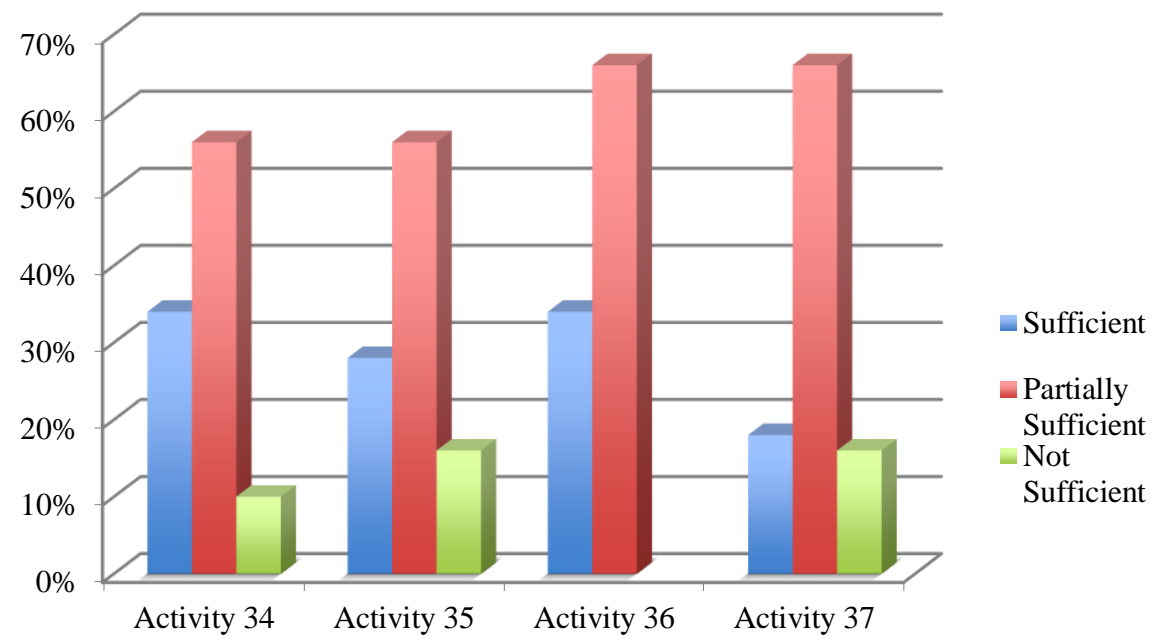

Figure 5. Distribution of Perceptions of Instructional Activities within Knowledge of Context

\section{Reflections on the Implementation of Teacher Knowledge Base of Teaching}

Findings on the pre-service teachers' (PSTs') reflections showed that the PSTs were not able to comprehensively elaborate the implementation of teacher knowledge base of teaching in their actual microteaching practices. Their 
answers to the reflective questions (see Appendix 2) did not thoroughly explicate how they actually implemented the knowledge.

In terms of the implementation of knowledge of learners, the majority of the PSTs stated that they had integrated their prospective students' learning needs relevant to the core and basic competences of the national EFL curriculum into specific learning objectives and instructional materials. Such reflective answer is represented below.

First of all, I will observe what students need in the class. After I know about what they need, then I will provide materials that suit their needs. For example, for grade XII of Senior High School, for learning procedure text, I provided some tips/manuals that were beneficial for them such as how to choose the right major in college, how to organise an essay, etc. (Respondent 5)

In response to the questions on the implementation of pedagogical knowledge, all the PSTs mentioned particular points that are parts of the principles of language teaching and learning. However, those principles were not holistically expounded. For example, when asked to reflect on how they taught text types, they showed their familiarity with text features and activities relevant to particular stages of the teaching and learning cycle of text-based teaching, but they did not give a complete portrayal of their application of textbased teaching. This is illustrated in the following reflective answer.

In my microteaching class, I used text-based approach/GBA, and taught the target text properties in the MOT stage. In the stage, I provided some examples of texts with their generic structures and linguistic features. I also provided some practices for the students to make sure that they had comprehended the use of the linguistic features on the text. (Respondent 11)

Still concerning the pedagogical knowledge, the PSTs mentioned some principles of teaching the four skills of English, such as, dividing their instructional design into two cycles comprising spoken cycle, which integrates listening and speaking skills, and written cycle, which is a blend of reading and writing skills; integrating the four English skills into communicative activities; and sequencing the teaching of the four skills into listening, speaking, reading and writing. With regard to the integration of content categories, such as, moral and cultural values, $21^{\text {st }}$ century learning skills, and higher order thinking skills, the majority of the PSTs did not provide any answers. Ten PSTs, however, reflected that they integrated these content categories into several learning 
activities. For instance, communication skills were built through such activities as story-telling and information exchange activities; collaboration skills were developed by assigning group works; critical thinking skills were instilled through the provision of critical questions related to the texts taught; and creativity was developed through the making of texts.

Communication: the students were asked to say or express their opinions on a particular topic to other students; Collaboration: the students were asked to work in pairs or groups; Critical thinking: the students were given some deeper/abstract questions related to the topic which was being taught; Creativity: students were asked to create their own text or do a project and then design and decorate themselves. (Respondent 1)

In response to the reflective question on exploring materials development practices, the majority of the PSTs' reflective answers showed that they were aware of and practiced the processes of materials development. They briefly stated that in developing instructional materials they relied on the internet and course books to search for materials. They also adapted authentic texts, sequenced the materials in accordance with the adopted methodology, and adjusted the materials to their student needs, as described in the following sample of a pre-service teacher's reflective answer.

When selecting the teaching and learning materials, I chose the materials that are suitable for my students. I also adapted and adopted the materials that I got from books or the internet. This is to make sure that the materials are the best for my students. Developing units is an important thing to do. It will make the students easier to follow the teaching and learning process and facilitate them with the materials that they need. (Respondent 5)

When the PSTs were asked to reflect on their activities in developing and using instructional media, they assured that the instructional media they used were suitable with the learning activities and the student needs. They mostly considered what, when, and how to use the media in their microteaching practices. The reflections of five PSTs also showed understanding of the functions of using media, such as, to increase students' involvement, support student learning, and motivate the students.

Regarding the practices of assessing student learning, the PSTs mentioned briefly that they conducted formative assessment by taking notes on how their students carried out the assigned learning activities, giving feedback, and 
checking their students' understanding through questions. Finally, the majority of the PSTs' reflections indicated their awareness of the role of socioeducational context. They stated that they incorporated their students' sociocultural background into the content of their selected texts.

In response to the last question asking about the actual problems the PSTs experienced during the microteaching sessions, most of the PSTs found it difficult to develop materials and manage the allotted time for their microteaching practices. Other problems, as confirmed in their reflections, were adjusting their instruction to their student needs, organizing and sequencing the lesson, and creating interactive and engaging learning activities.

To sum up, Table 2 identifies the major essential instructional activities within teacher knowledge base of teaching that the PSTs found challenging, as reflected from their perceptions as well as their reflections.

Table 2. Pre-Service Teachers' Challenges in Implementing Teacher Knowledge Base of Teaching

\begin{tabular}{lll}
\hline No. & $\begin{array}{l}\text { Knowledge } \\
\text { Category }\end{array}$ & Essential Activities \\
\hline 1. & $\begin{array}{l}\text { Knowledge of } \\
\text { Learners }\end{array}$ & $\begin{array}{l}\text { Applying ways of obtaining information about learner needs } \\
\text { Integrating learner needs into instruction } \\
\text { Reflecting the impacts of integrating learner needs into } \\
\text { instruction }\end{array}$ \\
\hline 2. $\begin{array}{l}\text { Content } \\
\text { Knowledge }\end{array}$ & $\begin{array}{l}\text { Delivering adequate knowledge of language (lexico- } \\
\text { grammatical knowledge, sound features, and discourse) }\end{array}$ \\
\hline & $\begin{array}{l}\text { Organizing the teaching and learning activities } \\
\text { Creating relevant techniques or interactive and engaging } \\
\text { learning activities based on the adopted organizing principle } \\
\text { Developing materials }\end{array}$ \\
& $\begin{array}{l}\text { Knowledge } \\
\text { Assessing student learning }\end{array}$ \\
\hline Knowledge of & $\begin{array}{l}\text { Interpreting the core and basic competences as stated in the } \\
\text { national curriculum }\end{array}$ \\
Curriculum & $\begin{array}{l}\text { Incorporating such content categories mandated by the } \\
\text { national EFL curriculum, Curriculum 2013, as values/ }\end{array}$ \\
\hline
\end{tabular}


Triastuti, Assessing English PSTs' Knowledge Base of Teaching 125

\begin{tabular}{lll}
\hline No. & $\begin{array}{l}\text { Knowledge } \\
\text { Category }\end{array}$ & Essential Activities \\
\hline & $\begin{array}{l}\text { characters, higher order thinking skills, and } 21^{\text {st }} \text { century } \\
\text { learning skills into instruction }\end{array}$ \\
\hline 5. & $\begin{array}{l}\text { Knowledge of } \\
\text { Context }\end{array}$ & Identifying aspects of socio-educational context \\
\hline 6. & Other Problem & $\begin{array}{l}\text { Managing time } \\
\text { Managing classroom (including varying classroom English) }\end{array}$ \\
\hline
\end{tabular}

\section{Discussion}

This study aimed to examine the extent to which pre-service teachers (PSTs) understand teacher knowledge base of teaching, and perceive and reflect its implementation in their microteaching practices. Overall, the findings of the study show that the PSTs' score averages in the teaching knowledge test were in line with their self-perceptions of the extent to which they had implemented the essential instructional activities in the teacher knowledge base of teaching (see Appendix 1). The PSTs rated the implementation of most of the instructional activities as "sufficient". However, some inconsistencies were also found. In terms of knowledge of context, for example, the PSTs' good score average did not correspond to their self-perceptions in accommodating their knowledge of context to their instruction. The PSTs perceived that they did not really do such a proper accommodation. Furthermore, the PSTs' reflective answers were not really in alignment with the good score averages and the generally positive self-perceptions. The reflections did not provide an adequate portrayal of how they managed the interaction of categories of knowledge within teacher knowledge base of teaching in their microteaching practices.

The conformity between the PSTs' test scores and self-perceptions found in this present study echoes the findings of Komur's (2010) study. Such findings revealed that pre-service teachers were able to obtain good scores of a teaching knowledge test and tended to positively perceive their teaching competence. Yet, good test results were not necessarily evident in their teaching performances and self-reflections.

The PSTs' limited and descriptive reflections in this study indicate their inability to practice reflection-on-action (Schon, 1983); such inability also reflects pre-service teachers' initial development. The PSTs' limited reflections 
suggest that their ability to self-reflect is still at a superficial level (FeimanNemser \& Buchmann, 1987), or reflects their "mechanical attitude" (Makina, 2018 , p. 12), and they are yet to demonstrate what so called "reflective deliberation" (Dewey, 1933, as cited in Griffiths, 2000, p. 544). Reflective deliberation enables teachers to bring into play a series of ideas that guide them to formulate required actions to inform their future instructional practices. There are several arguments that explain the PSTs' inability to engage in deliberate reflection. As teaching apprentices, beginning teachers lack teaching experience, and are, therefore, not capable yet of developing their "wisdom of practice, the maxims that guide (provide reflective rationalization for) the practices of able teachers" (Shulman, 1987, p. 11). Beginning teachers, including pre-service teachers, are also struggling to conceptualize their learning orientation (Korthagen, 1988), and are not yet able to view their teaching experience as rewarding experience that engages them with the balance of teaching practices and self-awareness (Farrell, 2013). The PSTs' reluctance in elaborating their self-reflections in this study may also indicate an attitude of viewing self-reflection in their teaching practicum simply as a course requirement rather than as a need to deeply reflect on their teaching practices (Tavil, 2014).

In response to the PSTs' insufficient ability to self-reflect in this study, several implications are drawn from research on English pre-service teachers' learning and reflection in their teaching practicum (e.g., Chien, 2014; Korkko, Kyro-Ammala, \& Turunen, 2016; Makina, 2018; Parsons \& Stephenson, 2005; Stenberg, Rajala \& Hilppo, 2016). To foster pre-service teachers' capability of self-reflecting, teacher education programs need to instill reflective practice in teaching practicum using particular strategies. It is feasible to implement the strategies studied by Chien (2014) and Stenberg et al. (2016). In Chien's (2014) study, pre-service teachers practiced to reflect on their experiential learning during their teaching practicum by being involved in videotaped simulated teaching practice and oral interviews, which were combined with peers' observations, peers' comments and teachers' comments. Meanwhile, Stenberg et al (2016) implemented a joint supervision by cooperating teachers and university lecturers so as to help per-service teachers better reflect on their experiential learning during their teaching practicum. Hence, such strategies exert rewarding teaching experience to pre-service teachers by systematically integrating self-awareness, which involves reflexive self-observation, selfmonitoring, and self-control (Farrell, 2013). Moreover, these strategies can 
effectively bridge "tension between vision and reality" (Yan \& He, 2010, p. 62) by strengthening a consolidation between university and school (Gan, 2014) to provide pre-service teachers with actual school reality.

The challenges as identified in Table 2 affirm similar findings of previous studies on novice and pre-service teachers' initial development of their knowledge and teaching competence (e.g., Komur, 2010; König et al., 2016; Kwo, 1996; Numrich, 1996; Yan \& He, 2010). Challenges, which are also translated into "frustrations" (Numrich, 1996, p. 142), denote novice and preservice teachers' developmental stages at their initial teaching experiences. Numrich's (1996) study has identified such particular challenges as managing time, accommodating learners' various needs, and assessing student learning, which are part of frustrations that novice teachers experienced in this study. The challenge of managing a classroom has also been confirmed as pre-service teachers' concern along with their self-image (Kwo, 1996). Likewise, Komur's (2010) study has recorded the challenges of managing a classroom and teaching content knowledge in the forms of grammar and language skills as part of pre-service teachers' difficulties. In line with the arguments advanced in the studies by Komur (2010), and Yan and He (2010), the pre-service teachers' challenges in this present study reflect their inability in channeling theories to their microteaching practices and their lack of practical knowledge to manage their classroom reality.

To respond to the difficulties, problems, frustrations, or challenges, as identified in these present and previous studies, teacher education programs need to formulate concrete and strategic follow-ups to strengthen pre-service teachers' understanding of teacher knowledge base of teaching and their reflective skills. To clearly draw the link between theories and practices, "an integrated approach" (Johnston \& Goettsch, 2000, p. 463) in teaching core teacher education subjects is worth adopting. This approach regulates the delivery of such subjects in a more integrated way, by involving the complex interaction of teacher knowledge base of teaching underlying teachers' pedagogical reasoning. To illustrate, such core subjects as Language Assessment and English Language Teaching Method, for example, are not presented in isolation; rather, their real application is explicated and explored within "the modularization of the knowledge base" (Johnston \& Goettsch, 2000 , p. 463), so as to enable pre-service teachers to see the relation between theories and practices (Farrell, 2013). In so doing, teacher education can enhance pre-service teachers' experiential learning so as to elevate their 
expertise in recalling and integrating their complex and multifaceted teacher knowledge base of teaching into their teaching practicum (see König et al., 2016).

\section{CONCLUSIONS}

This study examined whether the test results of pre-service teachers' knowledge base of teaching corresponded to their self-perceptions and reflections. It was revealed that the pre-service teachers' knowledge base of teaching was not fully mirrored in their self-portrayal. Their good scores in the teacher knowledge test and their overall positive self-perceptions of the knowledge implementation were not supported with vivid and thorough reflections to visualize the implementation of teacher knowledge base of teaching in their microteaching practices. In addition to these primary findings, the study has also identified the pre-service teachers' challenges in implementing the essential instructional activities within teacher knowledge base of teaching. The main challenges include integrating learner needs into instruction, delivering adequate knowledge of language, organizing the lesson, developing materials, assessing student learning, incorporating such mandated content categories of Curriculum 2013 as moral and cultural values, higher order thinking skills, and $21^{\text {st }}$ century learning skills into instruction, and managing a classroom.

Reflecting upon the findings, this study provides a map for understanding the essential instructional activities within teacher knowledge base of teaching that pre-service teachers find them challenging. Such a map is beneficial for teacher education programs to strengthen pre-service teachers' conceptualizations of their teacher knowledge base of teaching in designing and enacting their microteaching practices. To do so, teacher education programs can take strategic steps, such as, implementing an integrated approach (Johnston \& Goettsch, 2000) to link theory and practice, promoting simulated teaching practice and oral interviews (Chien, 2014), portfolio and journal writing (Korkko et al., 2016; Makina, 2018) to elicit pre-service teachers' critical reflection and pedagogical reasoning, and developing a mutual cooperation with schools to provide more realistic pictures of school realities to pre-service teachers (Gan, 2014; Parsons \& Stephenson, 2005; Stenberg et al., 2016; Yan \& He, 2010). Therefore, further research can comprehensively 
explore the implementations of such strategic ways to facilitate pre-service teachers' initial development of teaching expertise.

\section{REFERENCES}

Atay, D., Karlioglu, O., \& Kurt, G. (2010). The pedagogical content knowledge development of prospective teachers through an experiential task. Procedia - Social and Behavioral Sciences, 2(2), 1421-1425.

Bailey, K. M., Bergthold, B., Braunstein, B., Jagodzinski Fleischman, N., Holbrook, M. P., Tuman, J., Waissbluth, X., \& Zambo, L. J. (1996). The language learners' autobiography: Examining the "apprenticeship of observation". In D. Freeman \& J. C. Richards (Eds.), Teacher learning in language teaching (pp. 11-29). Cambridge University Press.

Chien, C.-W. (2014). Pre-service elementary school English teachers' learning and reflection through simulated teaching practice and oral interviews. Reflective Practice: International and Multidisciplinary Perspectives, 15(6), 821-835.

Farrell, T. S. C. (2013). Reflecting on ESL teacher expertise: A case study. System, 41, 1070-1082.

Feiman-Nemser, S., \& Buchmann, M. (1987). When is student teaching teacher education? Teaching and Teacher Education, 3(4), 255-273.

Gan, Z. (2014). Learning from interpersonal interactions during the practicum: A case study of non-native ESL student teachers. Journal of Education for Teaching: International Research and Pedagogy, 40(2), 128-139.

Gatbonton, E. (2008). Looking beyond teachers' classroom behavior: Novice and experienced ESL teachers' pedagogical knowledge. Language Teaching Research, 12, 161-182.

Griffiths, V. (2000). The reflective dimension in teacher education. International Journal of Educational Research, 33, 539-555.

Gudmundsdottir, S., \& Shulman, L. (1987). Pedagogical content knowledge in social studies. Scandinavian Journal of Educational Research, 31(2), 5970.

Holt-Reynolds, D. (1992). Personal history-based beliefs as relevant prior knowledge in course work. American Educational Research Journal, $29(2), 325-49$. 
130 TEFLIN Journal, Volume 31, Number 1, January 2020

Johnson, K. E. (1994). The emerging beliefs and instructional practices of preservice English as a second language teachers. Teaching and Teacher Education, 10(4), 439-452.

Johnston, B., \& Goettsch, K. (2000). In search of the knowledge base of language teaching: Explanations by experienced teachers. Canadian Modern Language Review, 56(3), 437-468.

Komur, S. (2010). Teaching knowledge and teacher competencies: A case study of Turkish pre- service English teachers. Teaching Education, 21(3), 279296.

König, J., Lammerding, S., Nold, G., Rohde, A., Strauß, A., \& Tachtsoglou, S. (2016). Teachers' professional knowledge for teaching English as a foreign language: Assessing the outcomes of teacher education. Journal of Teacher Education, 67(4), 320-337.

Korkko, M., Kyro-Ammala, O., \& Turunen, T. (2016). Professional development through reflection in teacher education. Teaching and Teacher Education, 55, 198-206.

Korthagen, F. A. J. (1988). The influence of learning orientations on the development of reflective teaching. In J. Calderhead (Ed.), Teachers' professional learning (pp. 35-50). Falmer Press.

Kwo, O. W. Y. (1996). Reflective classroom practice: Case studies of student teachers at work. Teachers and Teaching, 2(2), 273-298.

Loo, D. B., Maidom, R., \& Kitjaroonchai, N. (2019). Non-native English speaking pre-service teachers in an EFL context: Examining experiences through borderland discourse. Asia-Pacific Journal of Teacher Education, 47(4), 414-431.

Lortie, D. (1975). Schoolteacher: A sociological study. University of Chicago Press.

Makina, B. (2018). Exploring pre-service teacher development through daily journal reflections: A case study. African Education Review, 16(3), 67-83.

Miles, M. B., Huberman, A. M., \& Saldana, J. (2014). Qualitative data analysis: A methods sourcebook ( $3^{\text {rd }}$ ed.). Sage Publications, Inc.

Mullock, B. (2006). The pedagogical knowledge base of four TESOL teachers. Modern Language Journal, 90(1), 48-66.

Myhill, D., Jones, S., \& Watson, A. (2013). Grammar matters: How teachers' grammatical knowledge impacts on the teaching of writing. Teaching and Teacher Education, 36, 77-91. 
Numrich, C. (1996). On becoming a language teacher: Insights from diary studies. TESOL Quarterly, 30(1), 131-153.

Parsons, M., \& Stephenson, M. (2005). Developing reflective practice in student teachers: Collaboration and critical partnerships. Teachers and Teaching, 11(1), 95-116.

Riazi, A. M. (2017). Mixed methods research in language teaching and learning. Equinox Publishing Ltd.

Richards, J. C., Li, B., \& Tang, A. (1995). A comparison of pedagogical reasoning skills in novice and experienced ESL teachers. RELC Journal, 26(1), 1-24.

Saldana, J. (2013). The coding manual for qualitative researchers. Sage Publications, Inc.

Sanchez, H. S., \& Borg, S. (2014). Insights into L2 teachers' pedagogical content knowledge: A cognitive perspective on their grammar explanations. System, 44, 45-53.

Schon, D. A. (1983). The reflective practitioner. Basic Books.

Shulman, L. (1986). Those who understand: Knowledge growth in teaching. Educational Researcher, 15(2), 4-14.

Shulman, L. (1987). Knowledge and teaching: Foundations of the new reform. Harvard Educational Review, 57(1), 1-22.

Spratt, M., Pulverness, A., \& William, M. (2011). The TKT: Teaching knowledge test. Cambridge University Press.

Stenberg, K., Rajala, A., \& Hilppo, J. (2016). Fostering theory-practice reflection in teaching practicums. Asia-Pasific Journal of Teacher Education, 44(5), 470-485.

Tavil, Z. M. (2014). The effect of self-reflections through electronic journals (e-journals) on the self-efficacy of pre-service teachers. South African Journal of Education, 34(1), 1-20.

Trent, J. (2013). From learner to teacher: Practice, language, and identity in a teaching practicum. Asia-Pacific Journal of Teacher Education, 41(4), 426-440.

Tsui, A. B. (2003). Understanding expertise in teaching: Case studies of second language teachers. Cambridge University Press.

Yan, C., \& He, C. (2010). Transforming the existing model of teaching practicum: A study of Chinese EFL student teachers' perceptions. Journal of Education for Teaching: International Research and Pedagogy, 36(1), 57-73. 


\section{APPENDICES}

\section{Appendix 1}

\section{PERCEPTION SCALE OF PRE-SERVICE TEACHERS TOWARDS THE PRACTICE OF TEACHER KNOWLEDGE BASE FOR TEACHING IN MICROTEACHING CLASS}

Perceive to what extent you have integrated knowledge base for teaching, which consists of: 1) knowledge of learners, 2) content knowledge, 3) pedagogical knowledge, 4) knowledge of curriculum, and 5) knowledge of context, into your instruction (lesson plans and teaching practices) when taking micro-teaching class.

Rate your own perception towards the sufficiency of implementing your teacher knowledge base for teaching with the following scales: sufficient, partially sufficient, and not sufficient. Tick the scale that fits your perception.

\begin{tabular}{|c|c|c|c|c|}
\hline No. & $\begin{array}{c}\text { Essential Activities within Teacher } \\
\text { Knowledge Base for Teaching } \\
\end{array}$ & Sufficient & $\begin{array}{l}\text { Partially } \\
\text { Sufficient }\end{array}$ & $\begin{array}{c}\text { Not } \\
\text { Sufficient }\end{array}$ \\
\hline \multicolumn{5}{|c|}{ Knowledge of Learners } \\
\hline 1. & $\begin{array}{l}\text { Specifying important information } \\
\text { about the target students, for } \\
\text { example, students' needs and } \\
\text { students' characteristics. }\end{array}$ & & & \\
\hline 2. & $\begin{array}{l}\text { Using feasible ways/ techniques for } \\
\text { collecting information about the } \\
\text { target students. }\end{array}$ & & & \\
\hline 3. & $\begin{array}{l}\text { Assessing the feasibly } \\
\text { accommodated information about } \\
\text { the target students to instruction, for } \\
\text { example: } \\
\text { - Students' needs in terms of } \\
\text { wants, lacks, and necessities; } \\
\text { - Students' characteristics in terms } \\
\text { of levels of ability, learning } \\
\text { styles, interest. }\end{array}$ & & & \\
\hline 4. & Incorporating the components & & & \\
\hline
\end{tabular}


Triastuti, Assessing English PSTs' Knowledge Base of Teaching 133

\begin{tabular}{|c|c|c|c|c|}
\hline No. & \begin{tabular}{|c|} 
Essential Activities within Teacher \\
Knowledge Base for Teaching
\end{tabular} & Sufficient & $\begin{array}{l}\text { Partially } \\
\text { Sufficient }\end{array}$ & $\begin{array}{c}\text { Not } \\
\text { Sufficient }\end{array}$ \\
\hline & mentioned in no. 3 into instruction. & & & \\
\hline 5. & $\begin{array}{l}\text { Reflecting the impacts of integrating } \\
\text { information about the target students } \\
\text { into instruction. }\end{array}$ & & & \\
\hline 6. & $\begin{array}{l}\text { Using the reflection towards the } \\
\text { previous instruction to inform the } \\
\text { next instruction. }\end{array}$ & & & \\
\hline \multicolumn{5}{|c|}{ Content Knowledge } \\
\hline 7. & $\begin{array}{l}\text { Identifying what you want your } \\
\text { target students to learn in your } \\
\text { instruction. }\end{array}$ & & & \\
\hline 8. & $\begin{array}{l}\text { Being aware of kinds of content } \\
\text { categories for planning the content } \\
\text { of instruction, for example: } \\
-\quad \text { competencies, } \\
-\quad \text { language skills, } \\
-\quad \text { text types, } \\
-\quad \text { language features, } \\
-\quad \text { linguistic skills, } \\
-\quad \text { interpersonal skills, } \\
-\quad \text { learning strategies, } \\
-\quad \text { sociocultural skills, } \\
-\quad \text { integration of character } \\
\text { education (pendidikan karakter), } \\
-\quad 21^{\text {st }} \text { century skills (creativity, } \\
\text { critical thinking, collaboration, } \\
\text { communication). }\end{array}$ & & & \\
\hline 9. & $\begin{array}{l}\text { Mapping the selected content } \\
\text { categories and integrating them into } \\
\text { instruction. }\end{array}$ & & & \\
\hline 10. & $\begin{array}{l}\text { Transforming or changing the } \\
\text { selected content categories into } \\
\text { relevant teaching and learning } \\
\text { activities to meet the target students' } \\
\text { learning needs and the learning } \\
\text { objectives. }\end{array}$ & & & \\
\hline
\end{tabular}




\begin{tabular}{|c|c|c|c|c|}
\hline No. & $\begin{array}{c}\text { Essential Activities within Teacher } \\
\text { Knowledge Base for Teaching }\end{array}$ & Sufficient & $\begin{array}{l}\text { Partially } \\
\text { Sufficient }\end{array}$ & $\begin{array}{c}\text { Not } \\
\text { Sufficient }\end{array}$ \\
\hline 11. & $\begin{array}{l}\text { Mastering adequate knowledge of } \\
\text { language, for example: } \\
\text { - lexico-grammatical knowledge } \\
\text { that regulates how words and } \\
\text { grammar work in context, } \\
\text { - } \text { sound features that characterize } \\
\text { word stress and pronunciation, } \\
\text { and } \\
\text { - language functions, } \\
\text { to deliver meaningful instruction. }\end{array}$ & & & \\
\hline \multicolumn{5}{|c|}{ Pedagogical Knowledge } \\
\hline 12. & $\begin{array}{l}\text { Formulating relevant goals and } \\
\text { objectives as generated from the } \\
\text { core competence (Kompetensi Inti) } \\
\text { and basic competence (Kompetensi } \\
\text { Dasar) of the national curriculum } \\
\text { (Curriculum 2013). }\end{array}$ & & & \\
\hline 13. & $\begin{array}{l}\text { Formulating learning indicators that } \\
\text { represent relevant and doable } \\
\text { learning activities. }\end{array}$ & & & \\
\hline 14. & 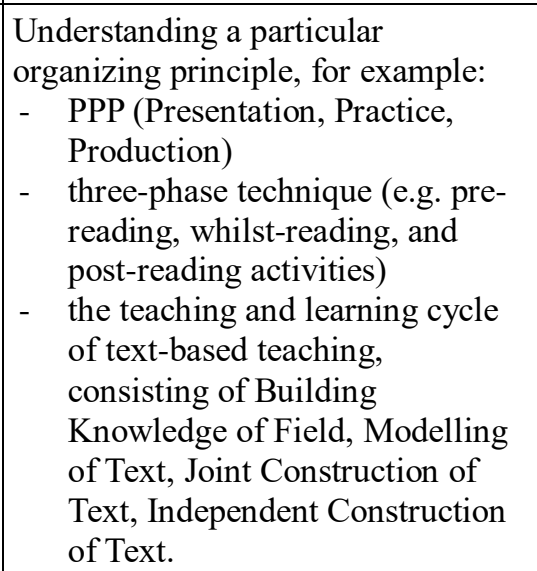 & & & \\
\hline 15. & $\begin{array}{l}\text { Applying a particular organizing } \\
\text { principle. }\end{array}$ & & & \\
\hline
\end{tabular}


Triastuti, Assessing English PSTs' Knowledge Base of Teaching 135

\begin{tabular}{|c|c|c|c|c|}
\hline No. & $\begin{array}{l}\text { Essential Activities within Teacher } \\
\text { Knowledge Base for Teaching }\end{array}$ & Sufficient & $\begin{array}{l}\text { Partially } \\
\text { Sufficient }\end{array}$ & $\begin{array}{c}\text { Not } \\
\text { Sufficient }\end{array}$ \\
\hline 16. & $\begin{array}{l}\text { Applying relevant techniques or } \\
\text { learning activities for each stage of } \\
\text { the selected organizing principle. }\end{array}$ & & & \\
\hline 17. & 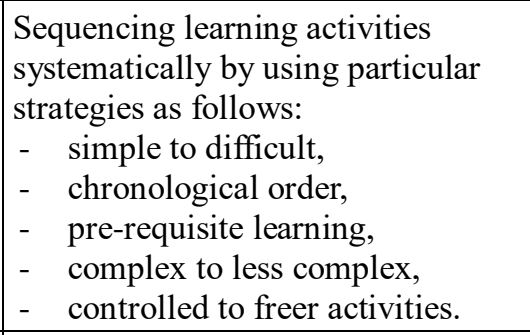 & & & \\
\hline 18. & $\begin{array}{l}\text { Making particular criteria, for } \\
\text { example: } \\
\text { - universal criteria, } \\
\text { - content-specific criteria, } \\
\text { - media-specific criteria, } \\
\text { - age/sex-specific criteria, } \\
\text { - categories-specific criteria, and } \\
\text { - local criteria, } \\
\text { for evaluating and selecting teaching } \\
\text { and learning materials. }\end{array}$ & & & \\
\hline 19. & $\begin{array}{l}\text { Implementing particular techniques } \\
\text { for adapting materials, for example: } \\
\text { - } \quad \text { addition/expansion/extending } \\
\text { material, } \\
\text { - } \quad \text { deletion/subtraction/reduction/sh } \\
\text { ortening material, } \\
\text { - } \quad \text { modification/replacement/changi } \\
\text { ng the methodology/changing } \\
\text { the level of the material, } \\
\text { - } \quad \text { reorganization/re- } \\
\text { sequencing/reordering material, } \\
\text { and } \\
\text { - } \quad \text { conversion/making use of all the } \\
\text { resources in the book, } \\
\text { to meet the students' learning needs, } \\
\text { the learning objectives, and the }\end{array}$ & & & \\
\hline
\end{tabular}




\begin{tabular}{|c|c|c|c|c|}
\hline No. & $\begin{array}{l}\text { Essential Activities within Teacher } \\
\text { Knowledge Base for Teaching }\end{array}$ & Sufficient & $\begin{array}{l}\text { Partially } \\
\text { Sufficient }\end{array}$ & $\begin{array}{c}\text { Not } \\
\text { Sufficient }\end{array}$ \\
\hline & defined context. & & & \\
\hline 20. & $\begin{array}{l}\text { Considering the level of authenticity } \\
\text { of materials (learning activities and } \\
\text { input texts). }\end{array}$ & & & \\
\hline 21. & $\begin{array}{l}\text { Adopting particular types of } \\
\text { assessment for assessing student } \\
\text { learning. }\end{array}$ & & & \\
\hline 22. & $\begin{array}{l}\text { Applying kinds of assessment } \\
\text { activities that offer varied } \\
\text { performance opportunities for the } \\
\text { students. }\end{array}$ & & & \\
\hline 23. & $\begin{array}{l}\text { Developing assessment criteria by } \\
\text { which the students' performances } \\
\text { will be assessed. }\end{array}$ & & & \\
\hline 24. & $\begin{array}{l}\text { Using relevant media to support } \\
\text { instruction. }\end{array}$ & & & \\
\hline 25. & $\begin{array}{l}\text { Giving opportunities to the students } \\
\text { to actively engage with the use of } \\
\text { media in doing learning activities. }\end{array}$ & & & \\
\hline 26. & $\begin{array}{l}\text { Using English language } \\
\text { appropriately for a range of } \\
\text { classroom functions, for example for } \\
\text { stimulating interaction, cooperation, } \\
\text { and teamwork in the classroom. }\end{array}$ & & & \\
\hline 27. & $\begin{array}{l}\text { Categorizing and correcting } \\
\text { students' mistakes. }\end{array}$ & & & \\
\hline 28. & Giving feedback. & & & \\
\hline 29. & $\begin{array}{l}\text { Using particular principles of } \\
\text { classroom management. }\end{array}$ & & & \\
\hline \multicolumn{5}{|c|}{ Knowledge of Curriculum } \\
\hline 30. & $\begin{array}{l}\text { Incorporating the core competence } \\
\text { (Kompetensi Inti) and the basic } \\
\text { competence (Kompetensi Dasar) as } \\
\text { stated in Curriculum } 2013 \text { into }\end{array}$ & & & \\
\hline
\end{tabular}


Triastuti, Assessing English PSTs' Knowledge Base of Teaching 137

\begin{tabular}{|c|c|c|c|c|}
\hline No. & \begin{tabular}{|c|} 
Essential Activities within Teacher \\
Knowledge Base for Teaching
\end{tabular} & Sufficient & $\begin{array}{l}\text { Partially } \\
\text { Sufficient }\end{array}$ & $\begin{array}{c}\text { Not } \\
\text { Sufficient }\end{array}$ \\
\hline & instruction. & & & \\
\hline 31. & $\begin{array}{l}\text { Incorporating some of main content } \\
\text { categories as mandated by } \\
\text { Curriculum } 2013 \text {, comprising: texts, } \\
\text { skills, values/characters, higher } \\
\text { order thinking skills, } 21^{\text {st }} \text { century } \\
\text { learning skills, into instruction. }\end{array}$ & & & \\
\hline 32. & $\begin{array}{l}\text { Reflecting whether learning has } \\
\text { taken place and the learning } \\
\text { outcomes have been met. }\end{array}$ & & & \\
\hline 33. & $\begin{array}{l}\text { Using the reflection to improve the } \\
\text { future instruction. }\end{array}$ & & & \\
\hline \multicolumn{5}{|c|}{ Knowledge of Context } \\
\hline 34. & $\begin{array}{l}\text { Observing the social, cultural, and } \\
\text { educational aspects that characterize } \\
\text { the context on which instruction is } \\
\text { based. }\end{array}$ & & & \\
\hline 35. & $\begin{array}{l}\text { Gaining specific information of the } \\
\text { context, for example characteristics, } \\
\text { constraints, strengths, on which } \\
\text { instruction is grounded. }\end{array}$ & & & \\
\hline 36. & $\begin{array}{l}\text { Considering information about } \\
\text { context for making pedagogical } \\
\text { decisions in planning and } \\
\text { implementing instruction. }\end{array}$ & & & \\
\hline 37. & $\begin{array}{l}\text { Integrating information about } \\
\text { context into planning and } \\
\text { implementing instruction, for } \\
\text { example the use of media, the } \\
\text { selection of input texts and learning } \\
\text { activities. }\end{array}$ & & & \\
\hline
\end{tabular}


138 TEFLIN Journal, Volume 31, Number 1, January 2020

\section{Appendix 2}

\section{TEACHING PRACTICUM REFLECTION OF PRE-SERVICE TEACHERS TOWARDS THE PRACTICE OF TEACHER KNOWLEDGE BASE FOR TEACHING IN MICROTEACHING CLASS}

In this part, please reflect back to your learning experience when planning and conducting your instruction at your microteaching class. Write your reflection in response to the following questions by providing some explanation and examples.

1. Looking back to your learning experience when taking micro-teaching class, explain what you did to answer the questions below:

a) What did you do to integrate the target students' learning needs into your instruction?

b) In what ways did you plan and teach the text properties (linguistic features, generic structure, communicative purpose)

c) In what ways did you plan and teach the English language skills?

d) In what ways did you incorporate character education, $21^{\text {st }}$ century skills (communication, collaboration, critical thinking, and creativity), and higher order thinking skills into your instruction?

e) What did you do to select and develop your teaching and learning materials?

f) What did you do to develop and use the instructional media?

g) What did you do to assess student learning?

h) In what ways did you integrate the social, cultural, and educational contexts into your instruction?

2. What problems did you experience in planning and practising the above instructional activities? 